\section{Trygt drikkevann}

Verdens helseorganisasjon Water safety plan manual

Step-by-step risk management for drinkingwater suppliers. $101 \mathrm{~s}$, tab, ill.

Genève: WHO, 2009. Pris CHF 20

ISBN 978-92-4-156263-8

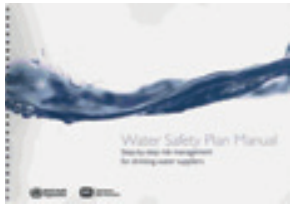

«Water safety

plan» er et uttrykk som det ennå ikke er funnet noen god norsk oversettelse for, til tross for at en del av prinsip-

pene har vært anvendt i drikkevannsforvaltningen her i landet i mange år. Det gjelder spesielt valg av drikkevannskilde, beskyttelse av kilden mot forurensning og beslutninger om nødvendig vannbehandling.

Water safety plan manual tar leseren skrittet videre på veien mot hygienisk sikkerhet helt frem til tappekranen. Den kan benyttes ved planlegging av nye anlegg og ved gjennomgang av eksisterende, og er også nyttig ved gjennomgang av et anlegg for å finne hva som må utbedres etter en eventuell hendelse som har utgjort en trussel mot folkehelsen.

Utgivelsen er oppbygd av moduler det gis en systematisk innføring $\mathrm{i}$ hvordan man bør håndtere de enkelte trinn i utviklingen mot en helhetlig plan. Det er forslag til løsninger og oversikt over tilgjengelig verktøy og - ikke minst - er det eksempler på hvordan problemer har vært løst i praksis på steder der man har anvendt konseptet. Dermed blir det innføring i både teori og praksis. Det gis en rekke forslag til enkle skjemaer for å systematisere oversikt over risikoforhold og risikovurderinger - gode bidrag til å forenkle prosessen frem til valg av adekvate løsninger.

Det pekes på viktigheten av å ha produksjonskontroll fremfor bare sluttproduktkontroll for å kunne være sikker på at vannkvaliteten til enhver tid er god nok. Produksjonskontrollen må være kontinuerlig (eller skje hyppig) på utvalgte kritiske kontrollpunkter, mens sluttproduktkontrollen kan skje sjeldnere fordi hensikten med den kun er å verifisere at produksjonen har gitt sluttproduktet riktig kvalitet. Kvalitetsavvik kan unngås ved at feil kan rettes før de har påvirket det endelige resultatet.

Flere av modulene kan også brukes som idégrunnlag for hvordan helsevesenet kan/ bør forholde seg til andre problemområder innen miljørettet helsevern der flere parter er involvert, områder hvor det faktisk er andre virksomheter enn helsevesenet som har det reelle gjennomføringsansvaret for helseverntiltakene.

Dette er en manual som ikke bare bør leses av vannverksansvarlige og Mattilsynet, den bør også leses av helsepersonell som er engasjert i miljørettet helsevern i kommunen. Også andre som har ansvar for kvalitetssikring, kan ha god nytte av å sette seg inn i de beskrevne metodene for tilnærming til en problemløsning.

\section{Truls Krogh}

Avdeling for vannhygiene

Nasjonalt folkehelseinstitutt

\section{Godt oppslagsverk om trafikksikkerhet}

Verdens helseorganisasjon Global status report on road safety

Time for action. $287 \mathrm{~s}$, tab, ill. Genève: WHO, 2009. Pris CHF 40 ISBN 978-92-4-156384-0

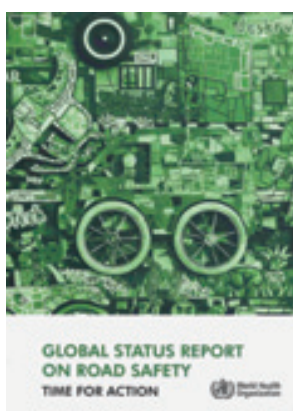

Dette er en utgivelse beregnet på alle instanser, organisasjoner og fagpersoner av ulikt slag som kan og bør delta i ulykkesforebyggende og personskadereduserende arbeid. En kartlegging av realitetene $\mathrm{i}$ tra-

fikkskadebildet er en forutsetning for å kunne arbeide målrettet. Det er her nedlagt et stort arbeid $\mathrm{i}$ innsamling av data fra de fleste land $i$ alle verdensdeler. WHO har deltatt i slikt arbeid i flere tiår, mest i uland, med faglig støtte fra i-land.

Mye av det forebyggende arbeidet har tidligere gått ut på å beskytte personer i kjøretøyene. Siden de myke trafikantene er de aller mest sårbare, beskrives deres situasjon, og det er forslag til spesifikke forebyggende tiltak overfor disse. Det legges særlig stor vekt på det tunge ansvaret de enkelte lands regjeringer har for å tilrettelegge for trygg trafikk og for å prioritere ressurser til både forebyggende tiltak og god livreddende og skadereduserende behandling.

Det er fire hovedkapitler: bakgrunn, behovet for en global kartlegging av trafikkulykkesproblemet, beskrivelse av situasjonen på dette felt rundt om i verden og til sist et kapittel med konklusjoner og viktige anbefalinger.

Som bakgrunn for de etterfølgende vurderinger brukes dødsårsaksstatistikken fra 2004. Denne omfatter de 15 hyppigst forekommende dødsårsaker fordelt på ulike aldersgrupper. Trafikkulykkene kommer her meget høyt opp: nr. 1 i aldersgruppen 15-29 år og nr. 2 i gruppene 5-14 år og 30-44 år. Trafikkulykkene veier også tungt i de øvrige aldersgrupper. Disse realiteter tilsier at det er behov for en bred kartlegging av alle deler av dette store helsepro- blemet for derved å legge et godt grunnlag for økonomisk prioritering av praktiske løsninger.

I kapittel 2 gis det en oversikt over arbeid som er gjort og som kan brukes som grunnlag for videre planlegging av globale tiltak. Det er også en god metodeoversikt.

I kapittel 3 legges det frem en rekke data som beskriver ulikhetene mellom kontinentene. Det anføres at få land har gode trafikksikkerhetslover som blir etterlevd av både myndigheter og veifarende. Fartsforhold, ruspåvirkning hos førere av motorkjøretøyer samt brukshyppighet av sikkerhetsutstyr gis en generell vurdering og omtale. Det påpekes at bruken av bilbelter, hjelm for syklister og forere av motoriserte tohjulinger må være konsekvent. Sikring av barn i bil gis særskilt omtale, og den vel dokumenterte kunnskapen om at de minste barna må sitte i en godkjent bakovervendt stol i baksetet, illustreres godt.

Et særlig sterkt innslag i mange deler av Global status report on road safety er påpekingen av at det er for dårlige statistikker og dermed store mørketall. Det er vel kjent at det er store mørketall også i land med lang tradisjon i ulykkesforebyggende arbeid. Forholdene på dette punkt er til dels helt uoversiktlige på flere kontinenter og i mange land. Dette gjør det vanskelig å legge et solid myndighetsbasert grunnlag i dette arbeidet. En sterk oppfordring om å sikre pålitelige nasjonale statistikker over trafikkulykker og deres følger er et av bokens viktigste budskap. Det påpekes også at god akutthjelp i alle deler av behandlingskjeden ofte er avgjørende for utfallet både når det gjelder overlevelse og ev. varig men.

Tabeller og illustrasjoner er oversiktlige og fint presentert. Det er et eget stort vedlegg med statistikk fra alle omtalte land. Dette er interessant, selv med de begrensninger som er omtalt vedrørende pålitelighet. Det er 51 referanser til aktuelle artikler og oppslagsverk om trafikkulykker. I siste del før nasjonsoversiktene gis det en rekke anbefalinger til politiske myndigheter og andre som har medansvar for å forebygge trafikkulykker og redusere alvorlighetsgrad og antall personskader.

Dette er et godt overnasjonalt oppslagsverk som gir kunnskapsstøtte til alle som har ansvar i denne sammenheng, helsevesenets aktører innbefattet.

\section{Inggard Lereim}

Institutt for nevromedisin

Norges teknisk-naturvitenskapelige universitet

Oppgitte interessekonflikter: Anmelderen har i mange år vært fagrådgiver for WHO i trafikkmedisin. 